


\section{EU-NATO Partnership in 2017-2018 - Towards a New Model of Effective Response to Threats}

Since the late 1990s, the correlation between a transforming EU and NATO have become a means to safeguard European security. However, the path to implementing the strategic partnership of both organizations has been very difficult. Over the years, the reviving belief that European NATO countries should take greater responsibility for their own defense clashed with their limited capacities. The development of the EU Common Security and Defence Policy (CSDP) determined interactions between European countries and the United States on the NATO forum. The idea of strengthening European defense capacities outside NATO has assumed new meanings, as the aspirations of European countries and the opportunity to use the potential of both organizations have been growing in the changing conditions of political tensions and intensification of external threats. The strategic partnership of both organizations was recognized politically, formally and legally through the adoption of successive declarations and agreements, initiated by the joint EU-NATO Declaration on European Security and Defence Policy, signed on December 16, 2002, and the Berlin Plus agreement of 2003, regulating the principles of allowing the EU to use NATO resources and potential in its operations. The process of the institutionalization of mutual relations gradually intensified, while maintaining the fundamental assumption about the EU playing a complementary role to NATO in the area of defense. The United States has granted its support to the development of European defense capacities, maintaining close transatlantic cooperation. Since the beginning of cooperation, mutual relations have been volatile, due to disputes concerning the necessity and manner of responding to international events and the role of both organizations in achieving security goals. The 2003-2005 period was an example of regression in consolidating institutional ties between the European Union and NATO. The relations deteriorated due to the EU's disapproval of the intervention in Iraq. The incompatibility of US strategy with European priorities was clearly visible both after the George W. Bush administration took over, which launched extensive counter-terrorist activities after the September 11, 2001 attack, causing the greatest split in the political unity in the European Union, as well as after the Donald Trump administration assumed power. The institutionalization of cooperation is another factor having a strong impact on the mutual relations of both organizations, especially in terms of decision-making and organizational mechanisms.

The first period of stagnation in the relations of both organizations ended as the EU's position consolidated in the international arena following the adoption of the Lisbon Treaty (Bakker, Bishop, Drent, Landman, 2016). The implementation of its 
provisions in the following years coincided with multiple crises that member states had to face. Destabilization in the EU's neighborhood exacerbated the existing threats and triggered numerous new threats to European security. As a result, tendencies to enhance the EU's defense capacities intensified after 2012. EU member states used the Lisbon Treaty as a basis for many new institutional initiatives and solutions. This attempt to make true the European dream of a common defense policy had to trigger a reaction from NATO and lead to a redefinition of the principles and formula of the partnership between the European Union and the North Atlantic Alliance. The favorable conditions for the strengthening of the cooperation between the two organizations changed after Donald Trump assumed the office of US President in 2017. The change in atmosphere was due to the priorities adopted in US foreign policy that conflicted with European interests on the one hand, and the increasingly unstable cooperation within the EU on the other. The 2017-2018 period was also marked by a considerable decline in public trust in the European project in many member states, due to a growing wave of discontent with the EU having been unable to use its mechanisms to effectively respond to internal crises. The need to create a new transatlantic cooperation mechanism occurred against the backdrop of negotiations on Brexit.

This article presents an analysis of factors determining the state of European Union-NATO relations after 2017. In order to properly investigate the research problems identified, a qualitative selection of sources, such as legal acts and 'soft law' documents of the organizations concerned, has been employed. The research questions addressed in the analysis concern the sources and dynamics of changes in these relations. The answers are based on an examination of the determinants of behavior of participants in the decision-making process of both organizations. The considerations concern the transformation of the existing structure of interinstitutional relations and the most important determinants of changes in the relations between both organizations. The article is based on the assumption that, in the period analyzed, EU-NATO relations were highly dynamic, leading to a redefinition of existing links. The hitherto principle of correlation of tasks, based on the two organizations mutually complementing their respective potentials; and the asymmetry principle, due to the US dominance in the North-Atlantic Alliance, are both being modified. Increasing threats to European security in the aftermath of the destabilization emerging to the east and south of the European Union has translated into stronger interdependence while coinciding with the process of the transformation of internal structures in the EU and NATO.

\section{BETWEEN THE NEED FOR COOPERATION AND THE ABILITY TO TAKE ACTION}

EU-NATO relations were officially established in 2001, although the process of shaping their cooperation had been ongoing since the 1990s. From the beginning, the main goal of developing stronger ties was to promote greater European responsibility in defense matters (Kaim, 2017: 20-21; Raik, Jarvenpaa, 2017: 3-5). Mutual relations were governed by principles of partnership which include correlation based on the complementary authority of both organizations to resolve crises; equality and respect 
for the decision-making autonomy and interests of the European Union, NATO and their member states; respect for the principles of the United Nations Charter, referred to in both the Treaty on European Union and the Washington Treaty. In their political declarations, both organizations stated that their cooperation would contribute to the development of military capabilities, which would have an advantageous impact on achieving the goals of both organizations in the face of security challenges.

As the European Union and NATO were agreeing to launch their strategic partnership, they also entered the path of major internal political and institutional changes (Duke, 2008: 29-30). NATO evolved from a regional military alliance into a global security organization (Wallander, 2000: 705-735), and the EU launched its first crisis management operations, which marked the beginning of its security and defense policy being operationalized. A new map of strategic influences was drawn. These transformations took place in the conviction that NATO would provide guarantees of European defense, while recognizing the need to launch 'soft power' (Manners, 2002: 235-258). In this period, the concepts of 'normative power' and the EU's civilian power also emerged (Orbie, 2006: 123-128). The changing strategic environment shaped the relationship, including proposals to implement declared "strategic partnership" (Smith, Gebhard, 2017).

The cooperation of both organizations has gradually undergone political and military institutionalization. The former concerned various forms of formal and informal EU-NATO political cooperation, which include regular meetings at various levels - from that of ministers, through ambassadors, to expert groups of military representatives or advisors dealing with various issues of member states' defense policy (Koops, 2017: 315-339). Shaping the military dimension of cooperation was equally important. The office of the Deputy Supreme Allied Commander Europe, who operates within the structures of both organizations, is important (Howorth, 2017: 454-459). He holds the position of EU Operations Commander. The office of the Deputy Supreme Allied Commander Europe symbolizes the pursuit of effective cooperation between the two organizations in case of possible stagnation at the political level. The next level of cooperation initiated involves the European Union Military Committee (EUMC), which brings together EU defense ministers. Similar to the Deputy above, they also have a dual function. In addition to attending EU meetings, they participate in NATO meetings. This dimension of cooperation has turned out to be significant, because in practice the EUMC performs advisory functions towards the Political and Security Committee (PSC). In addition, the Chairman of the EUMC participates in joint NATOPSC meetings. The Lisbon reform resulted in significant changes in the work of the General Secretariat of the Council (GSC), which controls the flow of 'sensitive documents' regarding EU-NATO relations (Piasecki, 2010). The European Union Military Staff (EUMS), as a specific department of the GSC, has been directly associated with the High Representative of the EU. The EUMS comprises both civilian and military personnel seconded to the GSC by member states. Three different levels have thus been formed in EU-NATO cooperation: representatives of states, international personnel and military crew. In practice, the best effects are achieved when cooperation at all levels is good, but it is most difficult at the first level. There is no political agreement that goes beyond the limited scope of the Berlin Plus agreement. Additionally, 
the informal and ad hoc cooperation of both organizations which was the basic factor facilitating consensus during intergovernmental disputes in times of external crises began to fade away very quickly.

The first attempts to improve EU-NATO relations appeared as early as 2008. They were triggered by the actions initiated during the French presidency of the EU Council, including the concept of establishing a group for the coordination of operational activities of the EU and NATO - a forum for dialogue on strategic aspects of joint operations. In 2008, Denmark, Finland, Sweden and Norway presented a non-paper on EU-NATO relations, highlighting problem areas and necessary actions, including closer cooperation in crisis management exercises, establishing periodical sessions of EU and NATO working groups, enhancing cooperation between the European Defence Agency (EDA) and NATO, and launching support programs for officials. However, these attempts were futile. In the following years, each organization focused on its own internal transformation and determining new roles on the international stage. Members of the Alliance debated the framework of a new strategic concept while the EU, with great difficulty, developed a coherent concept for its political development as an active participant in international relations. The disproportion of their military potentials had a fundamental impact on NATO-EU relations. A lack of military and financial resources in EU countries delayed the decision regarding the development of their defense capabilities and in a way 'condemned' the EU to military cooperation with NATO.

Many factors have had an impact on the revival of the debate on strengthening EU-NATO ties. First and foremost, the external threats caused by the destabilization of the EU's neighborhood in the aftermath of the Arab Spring and the Russian-Ukrainian conflict turned out to be significant. In 2012-2013, questions about the role of each organization in the area of security within the EU and abroad were asked again. The opinion was no longer valid that the CSDP is a European experiment - an attempt to create a complementary crisis management mechanism, to reform the security sector and achieve stabilization, while NATO remains mainly the organizational and strategic benchmark for European defense (Zyla, 2016: 303-304). In fact, both organizations have rejected their traditional roles, thus reviving the discussion on the organizational rivalry of both entities. On December 20, 2013, the European Council held an important debate on defense. Its conclusions included a list of priority actions for strengthening EU defense policy (EC Conclusions..., 2013). Importantly, this was the first meeting of the heads of government and state devoted to defense since the Treaty of Lisbon had come into life. The European Council summit was preceded by a meeting with the NATO Secretary General, who presented the full spectrum of security challenges facing the two organizations and expressed his approval for EU activities, considering them to be in line with NATO principles and beneficial for the Alliance. Several priority actions were identified, focusing on three aspects: increasing the effectiveness, visibility and impact of the CSDP; intensifying the development of capabilities; and strengthening the European defense industry. The fragmentation of European defense markets, which threatens the stability and competitiveness of the European defense sector, was considered important. EU member states are expected in EC conclusions to take greater responsibility in the face of growing external threats. Almost every specific element of actions identified pointed to their complementarity with NATO 
activities within the agreed framework of the strategic partnership of both organizations and compliance with the decision-making autonomy and procedures of each of these two entities.

In 2016, the idea of creating a European Defence Union was revived. This was confirmed by a resolution adopted by the European Parliament on April 13, which stated that "a principal objective should be to move towards permanently pooled multinational military units, joint defence forces and the framing of a common defence policy which should ultimately lead to a European Defence Union" (EP Resolution..., 2016). The resolution stressed that this would require a permanent EU military headquarters to be established to improve military crisis management capability, and ensure contingency planning and the interoperability of forces and equipment. The European Parliament also supported the adoption of a White Paper on EU Defence, based on the EU Global Strategy, which was widely discussed at the time. The White Paper was strongly promoted by the Dutch presidency (January-June 2016), the program of which did not prioritize defense, but combined it with measures to reduce illegal migration. The new ideas were linked to the concept of close EU-NATO cooperation, which should guarantee the coordination of operations, and support the establishment of European capabilities to strengthen NATO in terms of territorial defense and independent intervention outside the EU. One proposal was to combine EU battle groups and NATO response forces.

These decisions were reflected in the intergovernmental and parliamentary debate at the time. The tendency emerged then to strengthen cooperation in the area of defense, primarily in the field of defense research, industry and cyber defense, through the joint acquisition and use of military capabilities. The necessity to use national defense budgets more effectively was noted. Representatives of the majority of member states in the Council voiced their opinion that the role of the EDA should be strengthened and its resources increased. This institutional foundation is not a sufficient guarantee of the effectiveness of EU activities. It was crucial that different states recognized that they had to take responsibility for building European capabilities and contributing to the strategic autonomy of the EU. The biggest controversy was caused by both the rising expenditure on military research through the EDA and the development of Europe's technological and industrial basis for the defense sector and the European defense market. The issues concerning the development of European intelligence and forecasting capabilities were also raised in the discussion on defense. Importantly, the blame for the lack of progress in defense capabilities was most often put on the European Commission. Although the political responsibility rested on state leaders, the European Commission was criticized for the insufficient coordination and failure to perform the tasks entrusted to it by the European Council in 2013 regarding the planned agenda for a comprehensive security system of EU supplies, the planned Green Paper on supervising industrial capacity for defense and security of sensitive sectors, and monitoring defense and security procurement. Within the Commission, its Vice-President, High Representative of the Union for Foreign Affairs and Security Policy Federica Mogherini played a specific role, which had been accepted at the intergovernmental level. She was in charge of numerous executive commitments related to the operationalization of political ideas regarding defense activities. One important issue to be dealt 
with was the lack of clarity regarding the guidelines and implementation rules for the mutual defense clause (Article 42(7) of TEU).

\section{BETWEEN THE NEED FOR COOPERATION AND STRATEGIC AUTONOMY}

On June 28, 2016, in response to the European Council's call made at the June 2015 Summit, the High Representative presented the document entitled Shared Vision, Common Action: A Stronger Europe. A Global Strategy for the European Union's Foreign and Security Policy, which announced the strengthening of the EU in the field of defense (Shared..., 2016). The strategy calls on EU countries to jointly take responsibility for their own security, in particular it proposes to gradually align national defense planning cycles. The mechanism of synergy of defense and other elements in the area of the internal security of the EU was emphasized. For example, the possibilities of correlating CSDP missions and operations with the European Border and Coast Guard and specialized EU agencies to improve border protection were pointed out. Effective activities in the areas of security and defense were to rely on a strong defense industry, interoperability, an increase in financial resources to support defense research and technologies, and better use of the potential of the EDA.

The strategy also addressed EU-NATO relations. The relevant provision was a kind of confirmation of the status quo in these relations and of the belief that NATO remains the main structure of collective defense for most member states. It also stressed that the EU would deepen cooperation with the North Atlantic Alliance "in complementarity, synergy, and full respect for the institutional framework, inclusiveness and decision-making autonomy of the two." At the same time, the strategy confirmed the political will to strengthen the EU as a secure community operating autonomously and in cooperation with NATO. What was called an attempt to build a "credible European defence" was to help maintain "a healthy transatlantic partnership" with the United States. The adoption of this document also constituted the "appropriate strategic specification" which set the framework for further action by NATO in its relations with the EU (Duke, 2016: 154). The intensive EU work to strengthen defense capabilities resulted in yet another attempt to link EU activities with NATO (Bendiek, 2017: 18-19). In July 2016, a meeting at the highest level was held at the NATO summit in Warsaw, after which the President of the European Council, the President of the European Commission and the Secretary General of NATO adopted the Joint Declaration on EU-NATO Cooperation (Joint declaration..., 2016). In the face of new challenges, the declaration was an expression of closer mutual cooperation.

In 2016, a number of strategic documents were drafted directly or indirectly regarding the future of EU defense policy. One of them certainly includes the State of the Union speech delivered by Jean-Claude Juncker on September 14. Among many issues important for the future of the EU, the President of the EC mentioned the establishment of a single headquarters for EU civilian missions and military operations and creation of the European Defence Fund (Juncker, 2016). The political will to strengthen EU cooperation in the field of security and defense was also confirmed in the con- 
clusions from an informal summit of 27 member states on September 16, 2016, called the Bratislava roadmap (Bratislava declaration, 2016). The United Kingdom did not participate in the summit. The specter of Brexit was hanging over the future of the European project. However, the weaker influence of the United Kingdom, which had left the table where the future of the EU was being discussed, increased the impact of supporters of building a defense union (Whitman, 2016: 42-50; Blagden, 2017: 1-25). It is worth emphasizing that the EU negotiation limits were set from the start by the Chief Negotiator for the United Kingdom Exiting the European Union, Michel Barnier who, in a speech in Berlin in November 2017 said that the UK "will no longer be involved in decision making, nor in planning our defence and security instruments. It may no longer command an EU - led operation or lead EU battlegroups" (Barnier, 2017). He added that an ambitious partnership is in the interest of the Union, but it cannot discriminate against other third countries. Brexit means the lack of necessary strategic enablers and the need for more flexible cooperation structures (Koppa, 2019: 20).

The roadmap was based on the provisions of the EU's Global Strategy and focused on three strategic priorities: responding to conflicts and external crises, supporting the development of external partners' capacities, and protecting the EU and its citizens. While the development directions indicated did not arouse any controversy, assigning future actions to these priorities became crucial. Four elements were indicated: launching a coordinated annual review on defense (CARD), establishing permanent structured cooperation (PESCO), establishing a military planning and conduct capability (MPCC), and strengthening EU rapid response instruments, including battle groups and civilian capability. In order to implement the Bratislava roadmap, in December, the European Council decided on a specific plan to implement security and defense activities (Implementation Plan..., 2016). A decision was also made to start implementing the EU-NATO joint declaration, signed in Warsaw on July 8, 2016. At the turn of 2016 and 2017, work on strengthening defense cooperation in the EU gained momentum. At the same time, the frequency of meetings between EU and NATO representatives increased. On December 15, 2016, the European Council approved the EU Council's conclusions on the implementation of the EU's Global Strategy and called on the High Representative to submit proposals in the field of security and defense (EC Conclusions..., 2016). At the same time, the European Council requested the EU Council to submit a progress report on security and defense work in March and announced that further strategic guidance would be presented in June 2017. On February 16, 2017, the European Parliament adopted resolutions containing proposals for EU reform, based both on existing treaty provisions and future treaty changes proposed (EP Resolution..., 2017), where the EP called for ultimately developing joint defense mechanisms, establishing a Council of Ministers of Defence, using permanent structured cooperation, as well as - in the context of potential future treaty changes - for the institutional strengthening of the Common Foreign and Security Policy (CFSP) and introducing provisions on the European Defence Union into primary law.

On March 6, 2017, the EU Council adopted conclusions on progress in implementing the EU Global Strategy in the area of Security and Defence in which the EU Council addressed the need to continue work on permanent structured cooperation (PESCO), which should be open to all member states, and on a coordinated annual 
review on defense (CARD). The EU Council also adopted the Concept Note on the operational planning and conduct capabilities for CSDP missions and operations. The note lists measures to improve the EU's responsiveness, including the establishment of a military planning and conduct capability (MPCC) within the EU Military Staff in Brussels, working under the political control and strategic guidance of the Political and Security Committee; and the creation of a joint support coordination cell of civil and military missions (Council conclusions..., 2017). On June 7, the long-awaited Reflection Paper on the Future of European Defence (Reflection Paper..., 2017) was adopted, opening a debate on various aspects of reforms leading to the strengthening of the EU's role, including future EU-NATO relations. The document prepared by Federica Mogherini presents various scenarios for achieving the Security and Defence Union. A lot of attention is devoted to the establishment of the European Defence Fund, which is to increase the efficiency of member states' spending on defense capabilities. The most interesting aspects of the debate that started involved the need to increase national defense spending to $2 \%$ of EU GDP, the new role of the European Defence Agency, the need to establish a format for EU Council meetings at the level of defense ministers chaired by the High Representative, the establishment of an EU battlegroup system as an element of permanent structured cooperation with a permanent civil-military headquarters, the establishment of a European armed force capable of deploying combat forces in high-intensity conflicts, developing binding guidelines for the launch of a mutual assistance clause, and closer relations between the CSDP and NATO. The above elements were analyzed in terms of the legal and political outcomes that could possibly result from the UK's exit from the EU for the development of the EU-NATO partnership. The coherence of EU member states' security relations with the United States has always been in danger of a potential incompatibility of the goals of the United Kingdom and Northern Ireland and of some Central and Eastern European countries. The first year of Donald Trump's presidency - 2017 - showed that the more disputes arose in EU-US relations, the greater were the ambitions of European countries to engage in autonomous actions in the field of safeguarding security, and the more precarious the EU-NATO cooperation mechanism became.

\section{BETWEEN TRANSFORMATION AND EFFECTIVE RESPONSE TO THREATS}

On July 10, 2018 in Warsaw, the President of the European Council Donald Tusk, the President of the European Commission Jean-Claude Juncker, and NATO Secretary General Jens Stoltenberg signed a joint declaration that provided for increased cooperation between the EU and NATO in seven key areas of activity (Joint declaration..., 2018), namely preventing hybrid threats; operational coordination, including maritime issues; cybersecurity and defense; defense capabilities; defense industry and research; and military exercises. The relative success of the EU-NATO cooperation in these fields lies in the added value that both organisations bring to the issue. The EU has a broad civilian toolbox and creates its role in building societal resilience and (dis)information campaigns (Drent, Kruijver, Zandee, 2019: 13). The adoption of this docu- 
ment was yet another expression of EU-NATO cooperation in countering common threats. It was revealed in the course of preparations for the signing of this declaration that the differences between European countries and the United States regarding the vision of the role of both organizations were getting deeper. This resounded in the words of the President of the European Council Donald Tusk, who referred to the earlier criticism from the President of the United States Donald Trump regarding the insufficient financial commitment of NATO countries to European defense. The EC President said: "Dear President Trump: America does not have, and will not have a better ally than Europe," and a moment later referred to the meeting of President Trump with Russian President Vladimir Putin in Helsinki: "It is always worth knowing who is your strategic friend, and who is your strategic problem" (Remarks..., 2018).

The new EU-NATO declaration appreciates European defense efforts and confirms that European allies have assumed responsibility for their security, including through PESCO and the European Defence Fund. The essential provision was reiterated, that the EU's role was complementary to NATO's activities and not an alternative to them. The EU-NATO declaration concerned improving the mobility of troops and equipment, countering terrorism, fighting migrant smuggling in the Mediterranean and fighting cyber threats. To a large extent, this document was the expression of the relations of two organizations evolving under internal crisis and operating amidst various external challenges and threats. The shape of these relations turned out to have been strongly impacted by the decision of the United Kingdom to exit the EU (Black, Hall, Fox, Kepe, Silfversten, 2017: 9-10; Martill, Sus: 846-850). In its project of the EU's multiannual budget for 2021-2027, the European Commission has proposed a 22-fold increase in defense spending to $€ 27.5$ billion. In this way, the mechanisms of the European Defence Fund and the Internal Security Fund can become important measures to strengthen the EU's defense capabilities.

EU-NATO cooperation has become a key part of the implementation of the EU Global Strategy, and of the NATO's strategic concept. The above initiatives and activities, including the launch of the European Defence Fund announced by the European Commission, are examples of the process of increasing investment to strengthen the defense capabilities required to deter and respond to external threats. They are not always a convincing response to the US partners, who accuse Europe of spending too little on defense. When analyzing the elements that affect the tightening of EUNATO relations in 2017-2018, the following factors should be indicated. Firstly, the EU needs NATO to secure EU territorial defense. EU member states neither are able to nor intend to build capacity in this area. This results in the conviction that a lower military deterrence potential of NATO could undermine the credibility of both organizations. Secondly, NATO needs the EU to contribute to developing European defense capabilities. EU mechanisms can help European countries enhance their transatlantic partner's activities on the international arena (Bishop, 2017). Thirdly, both organizations need each other to combat hybrid threats. In particular, NATO needs the EU's contribution in this area, because the EU has a broader, though not yet fully developed, capability to deal with hybrid threats within European countries. In the long run, these factors will affect the EU, maintaining its strategic autonomy and the consolidation of transatlantic ties. 
Since 2017, EU-NATO relations have primarily been shaped by elements such as the emergence of new threats to security, including international terrorism, cyber threats, and uncontrolled migration due to the destabilization of the EU's southern neighborhood; establishing the political priorities of member states in the face of cooperation difficulties and threats triggered by the actions of the Russian Federation. These threats have significantly influenced the structural transformations of both organizations, including their reforms, which have modified their goals and expanded the scope of their activities.

The EU and NATO members are defining their strategic priorities in a dynamically changing neighborhood. The existing connections of institutional structures have gradually and very slowly been transforming. At the same time, cooperation is increasingly required to cope with various multidimensional threats. The changes to EU-NATO interinstitutional cooperation are the result of internal destabilization caused by the growing differences of national interests, political negation of the potential to solve problems in the area of security by the structures of institutional cooperation that have been deemed as inefficient, and long-term stagnation in terms of providing positive incentives for intergovernmental cooperation. The need to launch mechanisms to respond to increasingly frequent crises significantly boosts the commitment of both strategic partners to enhance existing links. When determining the factors of mutual cooperation, attention should be given to the current dysfunctionality, which is based on political animosities regarding the role of both entities in the new balance of strategic forces, as well as European limitations of exercising an actual influence in the region. At the same time, we are witnessing a crisis of social confidence in international organizations as guarantors of mutual relations.

In the period concerned, we have witnessed intensified activities aimed at developing the EU's CSDP, particularly in three dimensions: its institutionalization, enhancing EU defense capabilities and transformation of EU-NATO interinstitutional relations. The provision about a new stage of creating European defense was symbolically included in the Global Strategy for Foreign and Security Policy. The implementation of its two main parts: countering terrorism and organized crime, and enhancing defense and building resilience, including critical infrastructure, is a challenge to be tackled over the next decade. The development of both CSDP and EU-NATO mutual relations will be determined by how the United Kingdom sees its relations with the EU after Brexit.

Given the growing tension in the relations of Germany and France with the United States, European initiatives, such as PESCO, are presented as a way of Europe becoming autonomous, at a time when the credibility of the United States as an ally has diminished. However, no current action by the EU will replace NATO alliance capabilities. The synchronization of these activities with the defense planning process in NATO is of utmost importance. If it is absent, the Alliance's political coherence may be significantly undermined. 


\section{REFERENCES}

Barnier M. Speech at the Berlin Security Conference, 29 November 2017, http://europa.eu/rapid/ press-release_SPEECH-17-5021_en.htm (10.2.2019).

Bendiek A. (2017), A Paradigm Shift in the EU's Common Foreign and Security Policy: From Transformation to Resilience, SWP Research Paper Stiftung Wissenschaft und Politik German Institute for International and Security Affairs, Berlin.

Bakker A., Biscop S., Drent M., Landman L. (2016), Spearheading European Defence: Employing the Lisbon Treaty for a Stronger CSDP. Report, The Hague, Netherlands Institute of International Relations 'Clingendael'.

Biscop S. (2017), How the EU Can Save NATO, Security Policy Brief, Number 83, Brussels, Egmont, Royal Institute for International Relations, March.

Black J., Hall A., Fox K., Kepe M., Silfversten E. (2017), Defence and Security after Brexit: Understanding the possible implications of the UK's decision to leave the EU, Compendium Report, RAND Corporation.

Blagden D. (2017), Britain and the world after Brexit, "International Politics" 54(1).

Bratislava Declaration, Bratislava, 16 September 2016, https://www.consilium.europa.eu/media/ 21250/160916-bratislava-declaration-and-roadmapen16.pdf (15.07.2018).

Council of the European Union, Council conclusions on progress in implementing the EU Global Strategy in the area of Security and Defence, 6 March 2017, Press Release 110/17.

Dakic O. (2015), The state of play of the EU-NATO partnership, European Leadership Network, August 28.

Drent M., Kruijver K., Zandee D. (2019), Military Mobility and the EU-NATO Conundrum, Cligendael Report, July.

Duke S. (2008), The future of EU-NATO relations: a case of mutual irrelevance through competition?, "Journal of European integration", 30 (1).

European Council Conclusions, 19-20 December 2013, EUCO 217/13.

European Council Conclusions, 15 December 2016, EUCO 34/16.

European Parliament resolution of 13 April 2016 on the EU in a changing global environment - a more connected, contested and complex world, 2015/2272)INI.

European Parliament resolution of 16 February 2017 on possible evolutions of and adjustments to the current institutional set-up of the European Union, A8-0390/2016.

Howorth J. (2017), EU-NATO cooperation: the key to Europe's security future, "European Security", 26(3), July.

Implementation Plan on Security and Defence, November 2016, https:/eeas.europa.eu/sites/eeas/ files/eugs_implementation_plan_st14392.en16_0.pdf(15.07.2018).

Joint declaration on EU-NATO cooperation by President of the European Council Donald Tusk, President of the European Commission Jean-Claude Juncker, and Secretary General of NATO Jens Stoltenberg, 10 June 2018.

Kaim M. (2017), Reforming NATO's Partnerships, SWP Research Paper 1/2017, Berlin.

Koops J. (2017), Theorising inter-organisational relations: the "EU-NATO relationship" as a catalytic case study, "European security", 26 (3).

Koppa M. E. (2019), The relationship between CSDP and NATO after Brexit and the EU Global Strategy, FEPS Studies, April. 
Manners I. (2002), Normative power Europe: a contradiction in terms?, "Journal of common market studies", 40 (2).

Martill B., Sus M., Post-Brexit EU/UK security cooperation: NATO, CSDP+ or 'French connection'?, "British Journal of Politicsand International Relations", Vol. 20(4).

Orbie J. (2006), Civilian power Europe: review of the original and current debates, "Cooperation and conflict", 41 (1): 123-128.

Piasecki M., Instytucjonalne relacje UE z NATO, http://www.psz.pl/117-polityka/instytucjonalnerelacje-ue-z-nato (11.08.2018).

Raik K., Järvenpää P. (2017), A New era of EU-NATO cooperation, How to make the best of a marriage of necessity. Report, ICDS, May.

Reflection Paper on the future of European defence, COM(2017)315 of 7 June 2017, https://ec.europa. eu/commission/sites/beta-political/files/reflection-paper-defence_en.pdf(11.08.2018).

Remarks by President Donald Tusk on EU-NATO cooperation, 10 July 2018, 448/18.

Smith S. J., Gebhard C. (2017), EU-NATO relations: running on the fumes of informed deconfliction, "European Security", Vol. 26.

Shared Vision, Common Action: A Stronger Europe. A Global Strategy for the European Union's Foreign and Security Policy, June 2016, https://eeas.europa.eu/sites/eeas/files/eugs_review_ web_0.pdf (2.4.2018).

Wallander C. A. (2000), Institutional assets and adaptability: NATO after the cold war, "International organization", 54 (4).

Whitman R. G. (2016), The UK and EU foreign, security and defence policy after Brexit: Integrated, associated or detached?, "National Institute Economic Review".

Zyla B. (2016), Who is keeping the peace and who is free-riding?, "International politics", 53 (3).

\begin{abstract}
The purpose of this article is to understand the factors determining the state of European Union-NATO relations since 2017. Current determinants of these relations are discussed alongside the structures of interinstitutional links between the two organizations. In order to properly investigate the research problems identified, qualitative selection of sources in the form of legal acts and 'soft law' documents of the organizations concerned has been employed. The research questions addressed in the analysis concern the sources and dynamics of changes in these relations. The answers are based on an examination of the determinants of behavior of participants in the decision-making process of both organizations. The article is based on the assumption that, in the period analyzed, the hitherto principle of correlation of tasks based on the two organizations mutually complementing their respective potentials, has been modified. Recurrent situations calling for a joint and multidimensional response to crises have considerably widened the potential scope of strategic commitment of both partners and contributed to their links becoming stronger. Intensified activities aimed at developing the EU's CSDP have occurred while political disputes regarding the role of both entities in the new balance of strategic forces have significantly multiplied. European limitations on exercising an actual military influence in the region impede the chances of effective cooperation between the two entities.
\end{abstract}

Keywords: European Union, NATO, defense policy, security 


\section{TRUDNE PARTNERSTWO UE-NATO W LATACH 2017-2018}

\section{STRESZCZENIE}

Celem artykułu jest wskazanie czynników warunkujących stan relacji Unia Europejska - NATO po roku 2017. Przedstawione zostały istniejące determinanty tych relacji, jak i istniejące struktury powiązań międzyinstytucjonalnych obu organizacji. W celu właściwego rozpatrzenia wskazanych problemów badawczych zastosowano dobór jakościowy źródeł w postaci wybranych aktów prawnych i dokumentów typu soft law omawianych organizacji. Pytania badawcze stawiane w prowadzonej analizie dotyczą źródeł i przejawów dynamiki zmian w relacjach. Odpowiedź na nie udzielona została w oparciu o ukazane determinanty zachowań uczestników procesu decyzyjnego omawianych organizacji. W artykule oparto się na założeniu, iż w omawianym okresie dotychczasowa zasada korelacji zadań UE-NATO oparta na uzupełnianiu potencjału obu organizacji uległa modyfikacji. Powtarzające się sytuacje wymagające wspólnego i wielowymiarowego reagowania na kryzys znacząco zwiększyły obszar możliwego zaangażowania obu strategicznych partnerów i przyczyniły się do wzmocnienia istniejących powiązań. Intensyfikacja działań na rzecz rozwoju WPBiO UE występuje w okresie, gdy znacząco wzrosła liczba sporów politycznych dotycząca roli obu podmiotów w nowym układzie sił strategicznych. Europejskie ograniczenia w zakresie realnych możliwości wojskowego oddziaływania w regionie, umniejszają szanse na efektywną kooperację obu podmiotów.

Słowa kluczowe: Unia Europejska, NATO, polityka obronna, bezpieczeństwo 
